\title{
Hydrochar as an Energy Alternative to Coal: Effect of Temperature on Hydrothermal Carbonization of Paper Board Mill Sludge
}

\author{
O. Sadish ${ }^{1}$, S. Paul Sebastian ${ }^{1 *}$, K. Sara Parwin Banu ${ }^{1}$ and R. Mahendran ${ }^{2}$ \\ ${ }^{1}$ Department of Environmental Sciences, Tamil Nadu Agricultural University, \\ Coimbatore, 641 003, Tamilnadu, India \\ ${ }^{2}$ Department of Bioenergy, Tamil Nadu Agricultural University, Coimbatore, 641 003, \\ Tamilnadu, India \\ *Corresponding author
}

\begin{abstract}
A B S T R A C T
Keywords

Hydrothermal Carbonization, Paper board mill sludge, Proximate analysis, Higher heating value, $\mathrm{H} / \mathrm{C}$ and $\mathrm{O} / \mathrm{C}$ ratio

Article Info

Accepted:

12 May 2019

Available Online:

10 June 2019

Hydrothermal Carbonization is a thermochemical conversion process in which a biomass is processed under hot compressed air to form carbon rich products called as hydrochar. Hydrochar is a hydrophobic, condensed and friable solid product with a fuel property similar to conventional non-renewable energy sources like coal and lignite. Hydrothermal Carbonization performed with Effluent Treatment Plant (ETP) sludge at a temperature range of $180-240^{\circ} \mathrm{C}$ for a time period of 4 hours in a hydrothermal autoclave reactor resulted in the production of hydrochar with good energy values thereby ensuring its utilization as an alternative to coal. The energy properties like higher heating value (15.25 $\mathrm{MJ} \mathrm{Kg}^{-1}$ ), energetic recovery efficiency $(69.8 \%)$ and energy densification (1.24) were found to increase after hydrothermal carbonization at $220^{\circ}$ for 4 hours.
\end{abstract}

\section{Introduction}

The sludge generation from treatment plants of pulp and paper mill varies from 0.3 to $1 \mathrm{~m}^{3}$ per ton of paper produced Priadi, Wulandari, Rahmatika, and Moersidik (2014). The sludge generated from ETP (Effluent Treatment Plant) of paper board mill possess enormous amount of organic matter that are generally managed by land filling, incineration, land reclamation and energy recovery through combustion Pervaiz and Sain (2015). This results in the creation serious environmental issues in the form of secondary pollution Karthikeyan and Balasubramanian (2010). These sludge materials are mainly composed of organic fractions in the form of cellulose and inorganic fractions due to the addition of salts during the paper manufacturing process Abdullah, Ishak, Kadir, and Bakar (2015). This organic composition serves as a promising precursor material for the 
hydrothermal carbonization process because of their hydrophilic nature. Additionally, these compounds are readily available with lower cost and lower energy requirements (Ho et al., 2014).

Hydrothermal Carbonization is a thermochemical conversion method of biomass wherein the wet biomass compounds are converted into a carbon-rich solid product under sub-critical water conditions called as Hydrochar. Hydrothermal treatments are performed under auto-generated pressure conditions where the water in the biomass acts as a precursor, reactant or catalyst thereby assuring completion of the process Jin et al., (2014). This process is carried out between the temperature range of $180^{\circ} \mathrm{C}$ and $280^{\circ} \mathrm{C}$ within the time period of 1 minute to several hours under an inert atmosphere Reza et al., (2014). This method ensures the upgrading of biomass into energetic solid fuels wherein relatively higher yield can be recovered from a range of biomass precursors under comparatively lower temperature and pressure Libra et al., (2011). A series of reaction mechanisms takes place during the hydrothermal carbonization process that includes hydrolysis, dehydration, decarboxylation, polymerization and aromatization. This results in the dissolution of part of feedstock materials into liquid phase and also into minor quantity of gaseous compounds Falco et al., (2013). This process is advantageous in the sterilization of sludge materials within shorter period of time wherein the hydrophilic sludge particles are converted to hydrophobic carbonaceous products with variety of environmental applications thus enhancing the drying properties of sludge materials Phasee and Areeprasert (2017). The fuel property in terms of higher heating value, $\mathrm{H} / \mathrm{C}$ and $\mathrm{O} / \mathrm{C}$ ratios have been evaluated which lead to the utilization of the hydrothermally formed carbon product as brown coal. This energy rich carbon material have already been produced with various precursor materials like cellulose, microalgae, anaerobically digested silage, municipal solid waste, distiller's grains and black liquor Kim, Lee, and Park (2014). Also, the fuel characteristics and process energetics of hydrothermally carbonized paper and pulp mill sludge at different temperature have also been studied wherein $240^{\circ} \mathrm{C}$ for 30 minutes showed an increased higher heating value by $6.8 \%$ as compared to raw biomass Areeprasert, Zhao, Ma, Shen, and Yoshikawa (2014). So, it becomes evident that the temperature plays an important role in the fuel characteristics of hydrochar. With an objective of sustainable management of paper board mill sludge and energy production, this work concentrates on the effect of temperature on hydrothermal carbonization of the paper board mill sludge so as to attain a ecofriendly solid fuel production technology

\section{Materials and Methods}

\section{Sampling and processing of Sludge}

Sludge samples were collected from ITC Ltd., Paper Board and Speciality Papers Division Unit, Coimbatore, Tamil Nadu, India. The collected sludge materials were stored in sample containers under $4^{\circ} \mathrm{C}$. The Initial characterization of sludge samples were carried after drying and pulverizing as mentioned under analytical procedures.

\section{Wet torre faction or hydrothermal carbonization}

The sludge samples were mixed before taking it in the reactor after which $60 \mathrm{~g}$ of sludge samples were taken in $100 \mathrm{ml}$ hydrothermal autoclave reactor followed by purging with nitrogen gas for attaining inert atmosphere. Then, the reactor was placed inside the hot air oven and the desired temperature was set up 
with the retention time of 4 hours as exhibited in the Figure 1. At the end of the process, the wet product was dried to form hydrochar which was stored in an air tight container for further characterization Nakason et al., (2018). The selected temperature levels include $180^{\circ} \mathrm{C}, 200^{\circ} \mathrm{C}, 220^{\circ} \mathrm{C}$ and $240^{\circ} \mathrm{C}$ with a residence time of 4 hours which were designated as 180-4, 200-4, 220-4 and 240-4 respectively.

\section{Analytical procedures}

The moisture content, volatile matter, ash content and fixed carbon content of the samples have been determined by following the analytical procedures of ASTM (American Society of Testing and Materials).

The elemental composition $(\mathrm{C}, \mathrm{H}, \mathrm{N}, \mathrm{S}$ and $\mathrm{O})$ of the samples were determined using Elementar Vario EL III at CHNS operating mode with digestion temperature of 950$1200^{\circ} \mathrm{C}$. The Higher Heating Value (HHV) of the samples were calculated from the elemental composition according to the correlation of Channiwala and Parikh Wilk (2016).

$\mathrm{HHV}\left(\mathrm{MJ} \mathrm{Kg}{ }^{-1}\right)=0.349 \mathrm{C}+1.1783 \mathrm{H}+$ $0.10055 \mathrm{~S}-0.1034 \mathrm{O}-0.0015 \mathrm{~N}-0.0211 \mathrm{~A}$

Where, C - Carbon, H - Hydrogen, S Sulphur, O - Oxygen, N - Nitrogen, A - Ash content

The Solid yield, Energy Densification, fuel ratio and energetic recovery efficiency of the samples were also calculated Lin et al., (2015).

Fuel Ratio $=$ Fixed Carbon $(\%) /$ Volatile matter $(\%)$

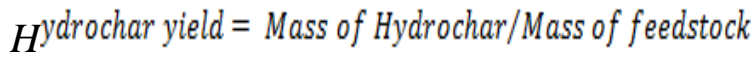

Energy Densification $=$ HHV of Hydrochar $/$ HHV of feedstock
Energetic recovery efficiency $=$ Hydrochar yield $X$ Energy Densification

\section{Results and Discussion}

The visual interpretation of sludge and different was carried out with the help of Figure 2 with special attention to color and texture. The dynamics in volatile matter, ash content and fixed carbon content has been shown in Figure 3. It can be seen that the volatile matter content of 240-4 have significantly decreased from $62.5 \%$ to $48.77 \%$ as compared to raw paper sludge that sums up to a reduction of $21 \%$. This reduction resulted due to dehydration and decarboxylation reactions Kim et al., (2014). On the other hand, the fixed carbon percentage increased from $7.5 \%$ for sludge to a maximum value of $13.92 \%$ for 240-4. Nevertheless, the increment in fixed carbon was lower than the loss in volatile matter thereby indicating conversion of volatile compounds into liquid and gaseous products respectively Lin et al., (2015). The main reason behind the loss of volatile matter is that the organic composition of paper sludge like carbohydrates, proteins, cellulose and hemicellulose compounds gets decomposed and dissolved into liquid and gaseous portions of hydrothermal carbonization as glucose, fructose, amino acids and phenolic compounds Román, Nabais, González, González- García, and Ortiz (2012). Also, the loss of volatile matter and retainment of mineral matter attributed towards the increase of ash content from $30 \%$ to $37.3 \%$ for $240-4$.

The fuel ratio and the Higher Heating Value (HHV) of the sludge and hydrochar samples were tabulated in table 1 . The significance of fuel ratio is to evaluate the alternative of a solid fuel. As a result of increased fixed carbon at higher temperatures, the fuel ratio tends to increase from 0.12 for sludge to 0.285 for $240-4$. The Higher Heating value increased gradually over the temperature rise, 
however, higher ash content generation at higher process temperatures decreased the heating value Lin et al., (2015). It can be seen that the HHV increased gradually and attained a maximum value of $15.25 \mathrm{MJ} \mathrm{Kg}^{-1}$ for $220-4$ and decreased for 240-4 (12.76 $\left.\mathrm{MJ} \mathrm{Kg}^{-1}\right)$ due to higher ash generation.

The coalification degree of the hydrochar can be assessed by Van Krevelen diagram (Fig. 4). Van Krevelen diagram encompasses the plotting of $\mathrm{H} / \mathrm{C}$ and $\mathrm{O} / \mathrm{C}$ atomic ratios in order to assess the fuel properties of the samples.
The $\mathrm{H} / \mathrm{C}$ and $\mathrm{O} / \mathrm{C}$ ratios of the sludge were 1.74 and 0.8 which reduced to a lowest value of 1.4 and 0.4 for 220-4 respectively. The extent of decarboxylation and dehydration can be assessed by this diagram wherein the H/C and $\mathrm{O} / \mathrm{C}$ ratios of conventional energy products like coal and lignin was compared. Generally, a compound with low $\mathrm{H} / \mathrm{C}$ and $\mathrm{O} / \mathrm{C}$ ratio can be considered as a fuel Kambo and Dutta (2014). It can be seen that the H/C and $\mathrm{O} / \mathrm{C}$ ratios of the hydrochar samples were close to $\mathrm{H} / \mathrm{C}$ and $\mathrm{O} / \mathrm{C}$ ratio of lignite Liu and Balasubramanian (2012).

Table.1 Elemental composition and energy properties of sludge and hydrochar

\begin{tabular}{|c|c|c|c|c|c|c|c|c|c|}
\hline Sample & $\begin{array}{c}\text { Carbo } \\
\mathbf{n}\end{array}$ & $\begin{array}{c}\text { Hydroge } \\
\mathbf{n}(\mathbf{\%})\end{array}$ & $\begin{array}{c}\text { Nitroge } \\
\mathbf{n}(\mathbf{\%})\end{array}$ & $\begin{array}{c}\text { Sulphu } \\
\mathbf{r} \\
(\mathbf{\%})\end{array}$ & $\begin{array}{c}\text { Oxygen } \\
(\mathbf{\%})\end{array}$ & $\begin{array}{c}\text { Higher heating } \\
\text { value (MJ Kg- }\end{array}$ & Fuel ratio & H/C ratio & O/C \\
\hline Sludge & 29.69 & 4.34 & 3.28 & 1.04 & 31.65 & 12.28 & 0.120 & 1.74229 & 0.80014 \\
\hline $\mathbf{1 8 0}-\mathbf{4}$ & 30.74 & 3.64 & 2.69 & 0.60 & 24.52 & 12.52 & 0.155 & 1.41275 & 0.59887 \\
\hline $\mathbf{2 0 0}-\mathbf{4}$ & 31.41 & 3.54 & 2.48 & 0.70 & 22.88 & 12.81 & 0.216 & 1.34235 & 0.54694 \\
\hline $\mathbf{2 2 0}-\mathbf{4}$ & 35.65 & 4.23 & 2.28 & 0.74 & 21.50 & 15.25 & 0.219 & 1.41486 & 0.45267 \\
\hline $\mathbf{2 4 0 - 4}$ & 31.26 & 3.68 & 2.45 & 0.74 & 24.56 & 12.76 & 0.285 & 1.40364 & 0.58962 \\
\hline
\end{tabular}

Fig.1 Experimental setup

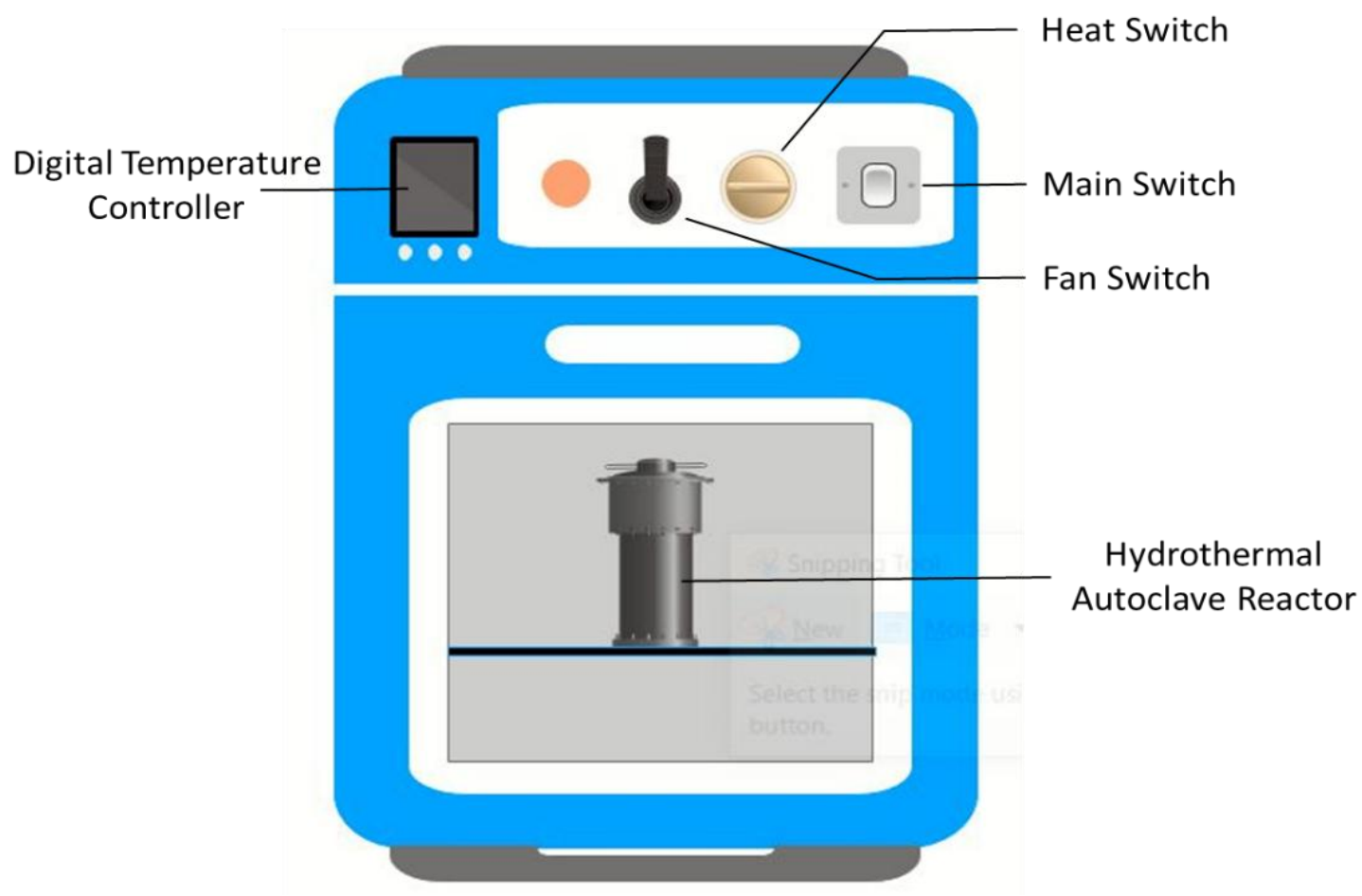


Fig.2 Visual interpretation of sludge and different hydrochar
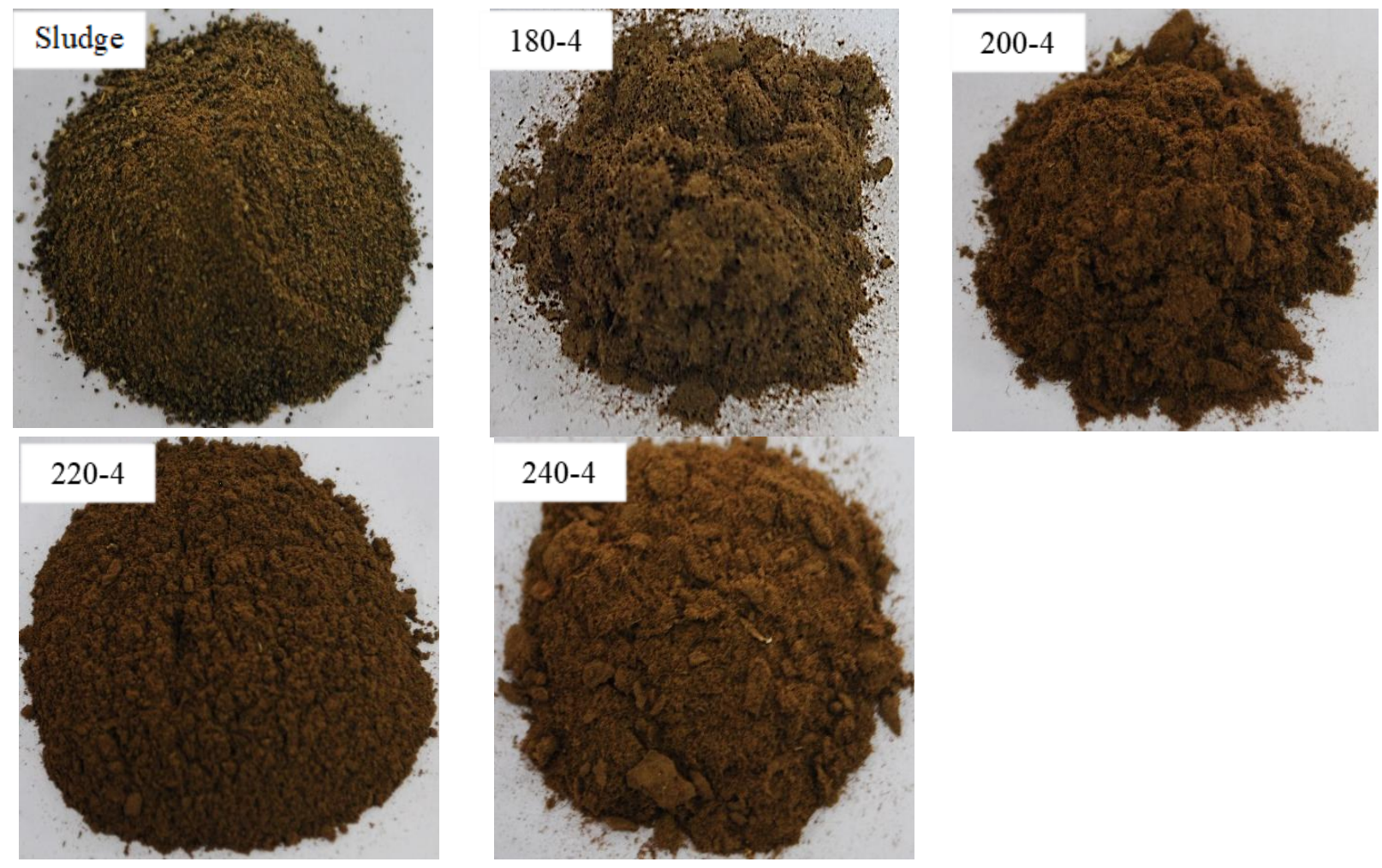

Fig.3 Proximate composition of sludge and hydrochars

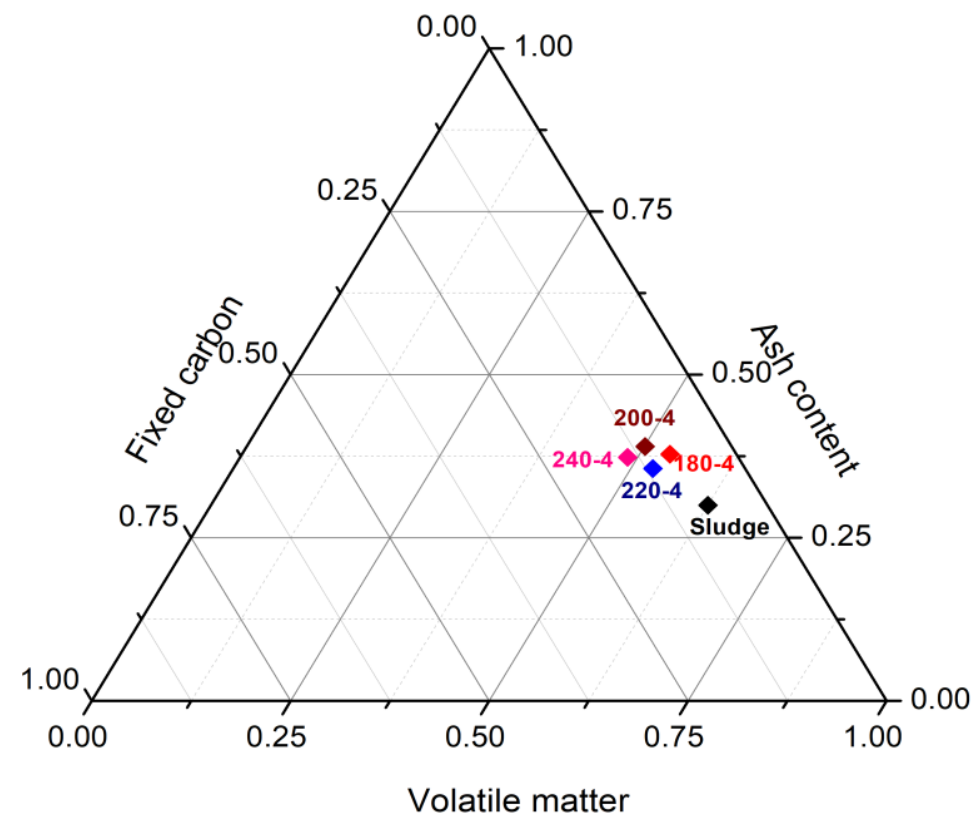


Fig.4 Van Krevelen diagram exhibiting the $\mathrm{H} / \mathrm{C}$ and $\mathrm{O} / \mathrm{C}$ ratios

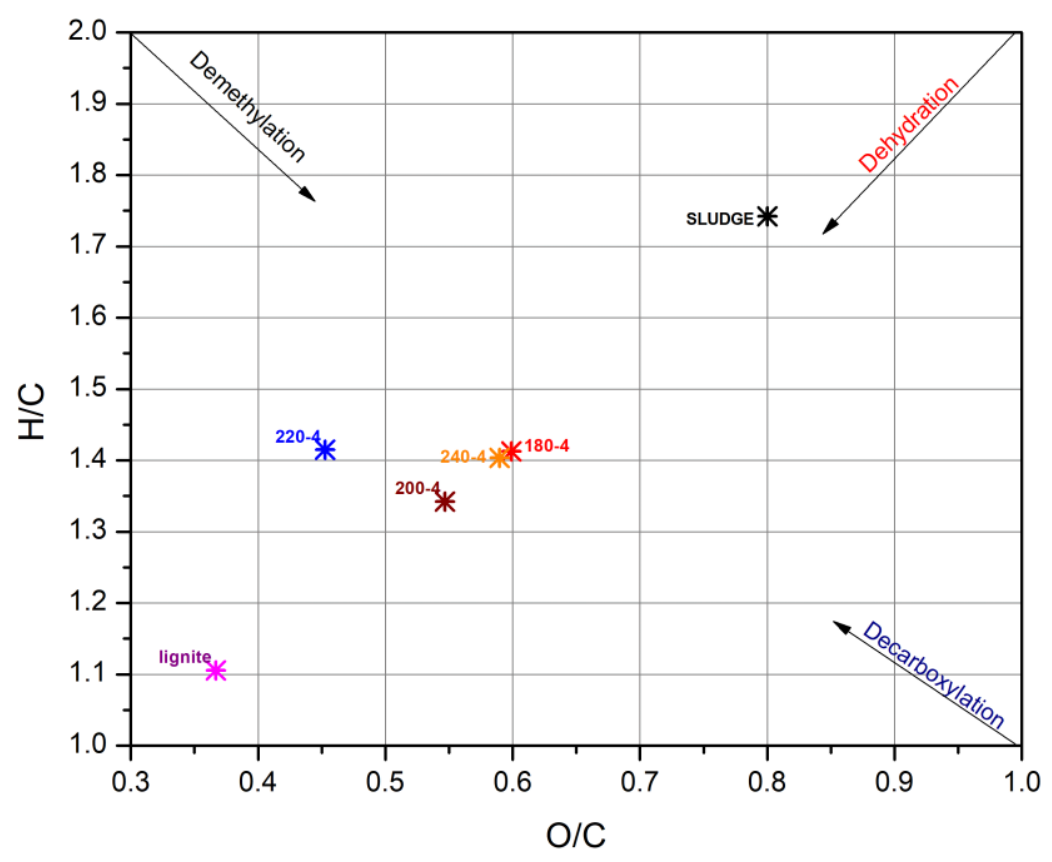

Fig.5 Solid yield, energy densification and energetic recovery efficiencies of hydrochar

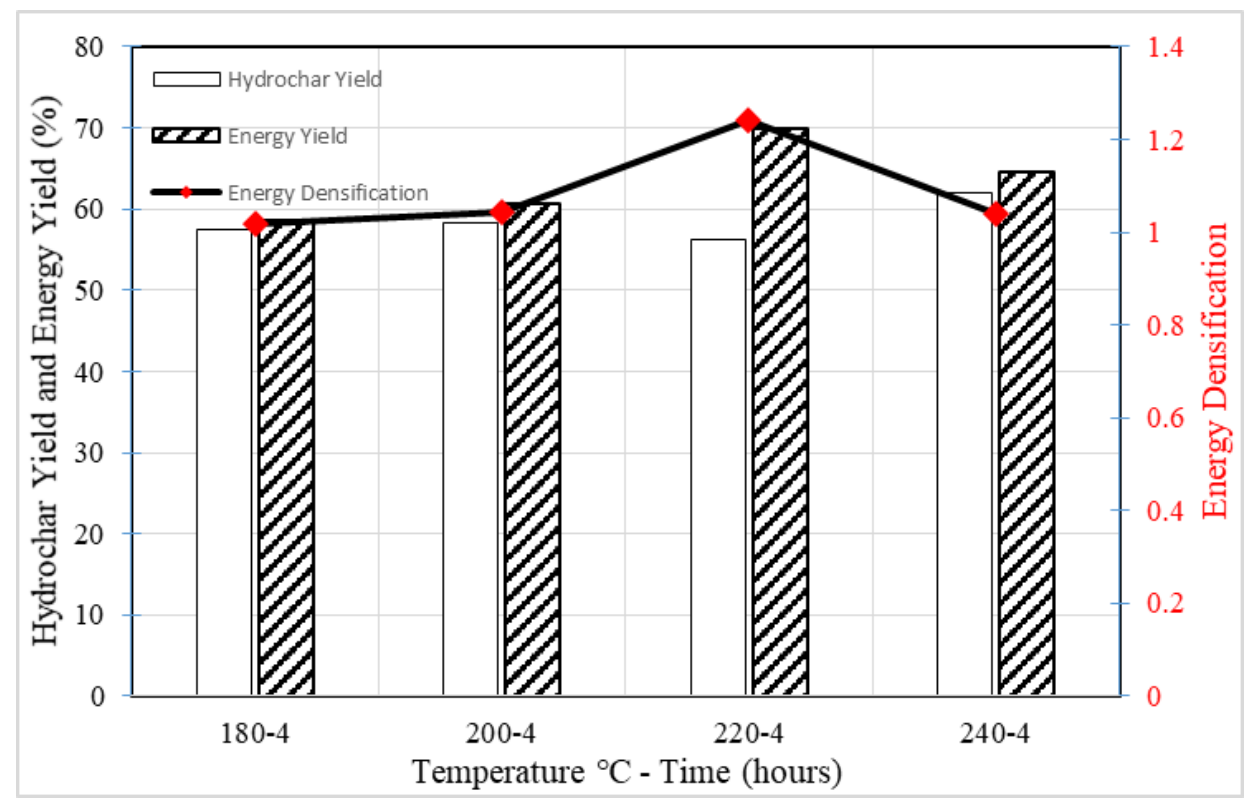

The Hydrochar yields, Energy densification and energetic recovery efficiency of the hydrochar samples were exhibited in the
Figure 5. The Hydrochar yield gradually increased over increased temperatures and attained a maximum yield of $62 \%$ for $240-4$ 
thereby confirming higher extent of condensation at higher temperature. The energy densification value of 180-4 was 1.01 and attained a maximum value of 1.24 for 220-4. However, 240-4 showed energy densification value lower than other values. The energetic recovery efficiency was used to evaluate hydrothermal carbonization process which followed a proportionality with energy densification. Highest energetic recovery efficiency have been obtained for 220-4 (69.8\%) followed by $240-4(64.4 \%), 200-4$ $(60.6 \%)$ and $180-4(57.4 \%)$ respectively.

The temperature changes on hydrothermal carbonization showed a significant effect on the energy properties of the hydrochar. It can be seen that 220-4 possessed good fuel property like higher heating value $(15.25 \mathrm{MJ}$ $\mathrm{Kg}^{-1}$ ), lower $\mathrm{H} / \mathrm{C}(1.41)$ and $\mathrm{O} / \mathrm{C}$ ratio $(0.45)$ and higher energetic recovery efficiency $(69.8 \%)$. Also, the energy densification values and hydrochar yield were also taken into consideration. However, certain upscaled studies involving economics of the process need to be carried out so as to promote sustainability.

\section{Acknowledgement}

The authors are thankful to ITC Ltd., (PSPD unit), Coimbatore for providing fund and support in carrying out research work and also thankful to the Department of Environmental Sciences, Tamil Nadu Agricultural University for helping in completion of work.

\section{References}

Abdullah, R., Ishak, C., Kadir, W., and Bakar, R. (2015). Characterization and feasibility assessment of recycled paper mill sludges for land application in relation to the environment. International journal of environmental research and public health, 12(8), 9314-9329.

Areeprasert, C., Zhao, P., Ma, D., Shen, Y., and Yoshikawa, K. (2014). Alternative Solid Fuel Production from Paper Sludge Employing Hydrothermal Treatment. Energy and Fuels, 28(2), 1198-1206. doi: 10.1021/ef402371h

Falco, C., Marco-Lozar, J. P., Salinas-Torres, D., Morallon, E., Cazorla-Amorós, D., Titirici, M.-M., and Lozano-Castelló, D. (2013). Tailoring the porosity of chemically activated hydrothermal carbons: influence of the precursor and hydrothermal carbonization temperature. Carbon, 62, 346-355.

Ho, D. P., Ngo, H. H., and Guo, W. (2014). A mini review on renewable sources for biofuel. Bioresour Technol, 169, 742749.

Jin, F., Wang, Y., Zeng, X., Shen, Z., and Yao, G. (2014). Water under high temperature and pressure conditions and its applications to develop green technologies for biomass conversion Application of hydrothermal reactions to biomass conversion (pp. 3-28): Springer.

Kambo, H. S., and Dutta, A. (2014). Strength, storage, and combustion characteristics of densified lignocellulosic biomass produced via torrefaction and hydrothermal carbonization. Applied Energy, 135, 182-191.

Karthikeyan, K., and Balasubramanian, S. (2010). Studies on the characterization and possibilities of reutilization of solid wastes from a waste paper based paper industry. Global Journal of Environmental Research, 4(1), 18-22.

Kim, D., Lee, K., and Park, K. Y. (2014). Hydrothermal carbonization of anaerobically digested sludge for solid fuel production and energy recovery. Fuel, 130, 120-125. doi: 10.1016/j.fuel.2014.04.030 
Libra, J. A., Ro, K. S., Kammann, C., Funke, A., Berge, N. D., Neubauer, Y., Kern, J. (2011). Hydrothermal carbonization of biomass residuals: a comparative review of the chemistry, processes and applications of wet and dry pyrolysis. Biofuels, 2(1), 71-106.

Lin, Y., Ma, X., Peng, X., Hu, S., Yu, Z., and Fang, S. (2015). Effect of hydrothermal carbonization temperature on combustion behavior of hydrochar fuel from paper sludge. Applied Thermal Engineering, 91, 574-582. doi: 10.1016/j.applthermaleng.2015.08.064

Liu, Z., and Balasubramanian, R. (2012). Hydrothermal Carbonization of Waste Biomass for Energy Generation. Procedia Environmental Sciences, 16, 159-166. doi: 10.1016/j.proenv. 2012.10.022

Nakason, K., Panyapinyopol, B., Kanokkantapong, V., Viriya-empikul, N., Kraithong, W., and Pavasant, P. (2018). Characteristics of hydrochar and liquid fraction from hydrothermal carbonization of cassava rhizome. Journal of the Energy Institute, 91(2), 184-193. doi: 10.1016/j.joei.2017.01.002

Pervaiz, M., and Sain, M. (2015). Recycling of paper mill biosolids: a review on current practices and emerging biorefinery initiatives. CLEAN-Soil, Air, Water, 43(6), 919-926.

Phasee, P., and Areeprasert, C. (2017). Thermal Decomposition Behavior during Combustion of Hydrothermally Treated MSW by Thermogravimetric Analysis. Energy Procedia, 138, 616621.

Priadi, C., Wulandari, D., Rahmatika, I., and Moersidik, S. S. (2014). Biogas Production in the Anaerobic Digestion of Paper Sludge. APCBEE Procedia, 9, 65-69. doi: 10.1016/j.apcbee. 2014.01.012

Reza, M. T., Andert, J., Wirth, B., Busch, D., Pielert, J., Lynam, J. G., and Mumme, J. (2014). Hydrothermal Carbonization of Biomass for Energy and Crop Production. Applied Bioenergy, 1(1). doi: 10.2478/apbi-2014-0001

Román, S., Nabais, J. M. V., González, J. F., González- García, C. M., and Ortiz, A. L. (2012). Study of the contributions of non- specific and specific interactions during fluoxetine adsorption onto activated carbons. CLEAN-Soil, Air, Water, 40(7), 698-705.

Wilk, M. (2016). A novel method of sewage sludge pre-treatment-HTC. Paper presented at the E3S Web of Conferences.

\section{How to cite this article:}

Sadish, O., S. Paul Sebastian, K. Sara Parwin Banu and Mahendran, R. 2019. Hydrochar as an Energy Alternative to Coal: Effect of Temperature on Hydrothermal Carbonization of Paper Board Mill Sludge. Int.J.Curr.Microbiol.App.Sci. 8(06): 1668-1675. doi: https://doi.org/10.20546/ijcmas.2019.806.199 